\title{
Professional Knowledge and Skills as a Key Factor in the Development of the Outsourcing of Financial and Accounting Services in Poland ${ }^{1}$
}

\begin{abstract}
Anna Bagieńska*
Access to professional knowledge and the skills of specialists is possible for many small companies thanks to the outsourcing of such services. The outsourcing of financial and accounting services is developing very dynamically in Poland. Many business process outsourcing centers and shared service centers have been established. Approximately $60 \%$ of companies in Poland make use of accounting companies. It was on the basis of questionnaire-based research looking at a group of entrepreneurs using outsourced accounting services that the reasons for having accounts managed by an outside company as well as factors behind selection of the accounting company and the extension of the agreement for a successive year were defined. The most important considerations determining collaboration include the quality of services as stemming from the competencies of the office staff, the range of services offered, advisory services in the area of financial management, accuracy in tax settlement, and the possibility of additional services. Due to today's high level of competition, the development of the outsourcing of financial and accounting services in Poland will be much more dependent on professional knowledge than price of services.
\end{abstract}

Keywords: outsourcing financial and accounting services, human capital, demand for specialized knowledge, entrepreneur.

Submitted: 10.06.2015 | Accepted: 26.09.2015

\section{Wyspecjalizowana wiedza i umiejętności determinantą rozwoju outsourcingu usług finansowo księgowych w Polsce}

Dostęp do specjalistycznej wiedzy, umiejętności specjalistów jest dla wielu małych przedsiębiorstw możliwy dzięki wykorzystaniu ustug outsourcingowych. W Polsce bardzo dynamicznie rozwija się outsourcing ustug finansowo-ksieggowych. Powstaje wiele Business Process Outsourcing Centres and Shared Service Centres. Okoto $60 \%$ przedsiębiorców w Polsce korzysta $z$ ustug biur rachunkowych. Na podstawie przeprowadzonych badań ankietowych $w$ grupie przedsiębiorców korzystających z zewnętrznych ustug księgowych określono przestanki decydujace o prowadzeniu rachunkowości przez zewnętrzna firmę oraz czynniki decydujace o wyborze biura i przedtużeniu umowy na kolejny rok. Najważniejszymi czynnikami decydujacymi o wspótpracy są: wysoka jakość świadczonych ustug wynikająca z kompetencji pracowników biura, oferowany zakres ustug, doradztwo w zarzadzaniu finansami, prawidtowość rozliczeń podatkowych, możliwość skorzystania $z$ dodatkowych ustug. W dobie dużej konkurencji o rozwoju outsourcingu ustug finansowo księgowych w Polsce zadecyduje w większym stopniu rosnacy popyt na wyspecjalizowana wiedzę niż cena świadczonych ustug.

\footnotetext{
Anna Bagieńska, Ph.D. - Department of Finance and Accounting, Faculty of Management, Bialystok University of Technology.

Mailing address: a.bagienska@pb.edu.pl. Ministry of Science
and Higher Education Republic of Poland

The creation of the English-language version of these publications is financed in the framework of contract No. 768/P-DUN/2016 by the Ministry of Science and Higher Education committed to activities aimed at the promotion of education.
} 
Słowa kluczowe: outsourcing usług finansowo-księgowych, kapitał ludzki, popyt na wyspecjalizowaną wiedzę, przedsiębiorca.

Nadesłany: 10.06.2015 | Zaakceptowany do druku: 26.09.2015

JEL: L21, M21, M12

\section{Introduction}

Knowledge and human capital are extremely important factors in the development of every company in the modern economy. The definition of an organization's human capital as found in literature is people permanently tied to the company and its mission, who know how to cooperate, and who have a creative attitude as well as qualifications. Human capital is the driving force of a company (Sajkiewicz, 2002). A. Pocztowski defined it as the sum of specific qualities and properties embodied in workers that have a defined value and are the source of future income for both the worker and for the organization utilizing that potential on defined terms (Pocztowski, 2003). In this paper, the concept of a company's human capital is understood as employee knowledge, education, and creativity that, through the process of accumulation, increase their value for the organization and play a role in improving its economic and social condition as well as company image and value. In the case of accounting offices, the process of accumulating human capital involves a conscious investment in workers (in their attracting, retaining, and development) and in gaining professional experience. On the one hand, the role of human capital in the development of financial and accounting services provided by accounting companies is dependent on perceiving knowledge and skills as development factors by the company owner. On the other, it depends on the demand for high quality services, both basic ones linked with accounting and tax settlement and additional services.

Professional knowledge in the realm of finance and accounting is vital in managing any activity, including by individual entrepreneurs and by small and medium enterprises. However, not all businesses are capable of employing workers with the necessary knowledge and skills for both financial reasons and organizational ones. Another reason is the economic inefficiency of establishing an in-house financial and accounting department in the case of small-sized companies. Another is the lack of a person with the relevant knowledge, competencies, and qualifications. Entrepreneurs who do not employ their own financial and accounting department staff can take advantage of the knowledge of specialists through outsourcing. Outsourcing is the isolation out of the company's own organizational structure of certain functions and handing them over to an outside entity (Trocki, 2001). Among external entities providing financial and accounting services are business process outsourcing centers, shared service centers, and accounting and bookkeeping offices providing individual services. Usually, large- and medium-sized domestic and foreign companies use the services of such centers. However, according to research conducted by the Starter Foundation, approximately $63 \%$ of entrepreneurs used the services of accounting companies, 9\% employ their own accountant, and approximately $28 \%$ manage their books independently by way of a computer program or online (Starter Business Development Foundation, Accounting Services in Poland, 2013). Accounting companies make up the most common form of outsourcing financial and accounting services on the Polish market.

The coming into force of regulations facilitating the rendering of accounting services - i.e. deregulation - is the source of many fears in the accounting community. ${ }^{2}$ The greatest of these is the vision of the emergence on the market of accounting offices employing accountants who lack the relevant qualifications, knowledge, skills, and experience. Their trump card will be low price. The outcome can be that businessmen, especially rookies, who use such services, may not have their accounts settled properly. Such errors can have serious consequences - tax and financial - and even have an impact on the continued operations of the company.

The goal of this paper is to analyze the role played by demand for specialized knowledge and skills in the development 
of the outsourcing of financial and accounting services as provided by accounting companies.

Analysis of the "Rok po deregulacji" [One year after deregulation] report as well as the results of a pilot questionnaire-based study examining a group of fifty-six businesses using outside accounting services was used to define the premises behind the keeping of accounting books by an external company as well as factors determining choice of company and extension of the agreement for a successive year. This research tries to verify the premise that a growing demand for specialized knowledge is behind the development of outsourcing financial and accounting services rendered by accounting companies in Poland to a greater extent than the price of services.

\section{The Outsourcing of Services in Light of the New Institutional Economy}

In neoclassical economic theory, the source of the division of labor is its positive impact on efficiency and the good of society. Contemporary companies are undergoing production fragmentation on the basis of contracts (by contracting out certain phases of the production process) or capital fragmentation involving the splitting up of the company into divisions. In line with the concept of company equilibrium (Radło, 2013), each company achieves its individual point of equilibrium when the difference between total revenues and total costs achieves its maximum. In other words, at the point at which the marginal cost curve intersects with the marginal revenue curve. A company will decide on fragmentation of production as long as profits at the new point of company equilibrium exceed profits at the point of equilibrium prior to production fragmentation. Jones and Kierzkowski (1988) proposed the subdivision of production processes into what are known as production blocks, which signify concrete elements of the production chain. These blocks consist of certain isolated production processes that are connected with each other through service processes, such as transportation or financial services. The development of so-defined fragmentation causes growth in demand for service processes connected with servicing the links between the production blocks
(Jones and Kierzkowski, 2003). As stressed by Trocki (2001), factors fostering further fragmentation of production include technological progress, growing aspirations on the part of the company to concentrate on key areas of operations, and increasing maturity of suppliers capable of meeting increasingly sophisticated customer needs. In effect, production fragmentation has evolved from the elimination from the company of simple processes in order to reduce costs, through a striving to reduce risk, concentration of key operations, all the way to the strategic selection of the way in which the company is to function (Ciesielska and Radło, 2013).

De Vita and Wang (2006) identified three generations of outsourcing of various service processes. The first involves the fragmentation of processes that are not coupled with the key competencies of the organization and reflect a striving to reduce employment costs. What are excluded are simple functions such as handling salaries, security, and janitorial services. This contracting out of functions is also often linked with their performance by more efficient suppliers. The second generation involves the exclusion from the company of processes other than ancillary ones - processes that are not considered key company competencies. The main motive here is a striving to improve efficiency and concentration on key competencies. The last generation of production fragmentation encompasses processes defined as key company competencies. The motives behind such fragmentation are improved efficiency and flexibility as well as increased innovativeness that is often forced by growing competition.

The appearance of new information technologies that made possible the quick and cheap storage and transfer of data ushered in the development of services by outside subcontractors. The revolution in the services trade resulted in making it possible for many business service processes, such as accounting, IT, and customer services, to be excluded from the parent company and be performed externally. Moreover, favorable legal solutions (i.e. the deregulation of professions such as accountant, tax advisor, etc.) facilitate the emergence of new companies providing various types of services.

Factors taken into account when a company decides to undertake fragmentation of 
both production and other functions performed in the company and with respect to the profitability of utilizing outsourcing have evolved in parallel with the development of outsourcing. The initial reasons behind fragmentation are competitive pressure. This is followed by concentrating on costs all the way to seeking additional benefits from outsourcing contracts (Tate, 2009).

\section{Financial}

\section{and Accounting Services as the Subject of Outsourcing}

Financial and accounting services are considered a part of the group of what are known as business services (Cyrek, 2012). Such services require professional knowledge vital to the proper performance of operations such as recording, settlement, reporting, and others in line with current legal solutions. Accumulated financial data are a source of information for businesses and have an impact on the management decisions they take. On the par with high-tech industries, science and research and development, education, and information society services, professional business services are considered carriers of the knowledge-based economy because their essence is the improvement of defined company processes thanks to the transfer of professional knowledge to business (Kuczewska, 2009).
Financial and accounting services, like other functions and processes, can be contracted out in the form of outsourcing. Pursuant to the Act on Accountancy, bookkeeping can be contracted to external entities involved in bookkeeping services. As stressed by Matejun, outsourcing is based on the "utilization of the competencies and skills of external, specialized entities so that they can concern themselves with tasks (processes and functions) that are usually not linked with the main area of operation of the parent company (separating activities from their structures)" (Matejun, 2011). Thus, this is an idea for expanding access to physical, information, and other intangible resources as well as people, without increasing the size of the parent organization.

It is especially small companies that are predisposed to the application of outsourcing in accounting, especially with respect to functions that require specialized knowledge and special skills. Research performed by Jarka indicates that $22 \%$ of SMEs outsource accounting (Jarka, 2011). One of the reasons for this is audits performed by state treasury bodies. This possibility makes managers and company owners aware of the need for high quality company tax documentation managed by suitably qualified economic entities (Zieliński, 2008).

The scope of financial and accounting services that can be performed by outsourcing service suppliers is shown in Table 1.

Table 1. Scope of Services Performed by Outsourcing Service Suppliers

\begin{tabular}{|l|l|}
\hline \multicolumn{1}{|c|}{ Scope of work } & \multicolumn{1}{|c|}{ Actions performed as a part of the individual tasks } \\
\hline $\begin{array}{l}\text { Commencement } \\
\text { of business } \\
\text { activities }\end{array}$ & $\begin{array}{l}\text { - Drafting founding acts, } \\
\text { - Assistance in registering the company with the National Court } \\
\text { Register (KRS) and the State Treasury, and } \\
\text { - Developing and implementing the chart of accounts. }\end{array}$ \\
\hline $\begin{array}{l}\text { Keeping tax and } \\
\text { social security } \\
\text { (ZUS) records }\end{array}$ & $\begin{array}{l}\text { - Keeping books on expenditures and revenues, } \\
\text { - Keeping a registry of VAT purchases and sales, }\end{array}$ \\
& $\begin{array}{l}\text { - Drafting employee monthly income tax declarations, } \\
\text { - Drafting monner monthly income tax declarations, }\end{array}$ \\
& $\begin{array}{l}\text { - Establishing tax amounts due, } \\
\text { - Employee annual tax returns, }\end{array}$ \\
& - Owner annual tax returns, and
\end{tabular}

Wydział Zarządzania UW DOI 10.7172/1733-9758.2016.20.4 
Table 1 cont.

\begin{tabular}{|l|l|}
\hline \multicolumn{1}{|c|}{ Scope of work } & \multicolumn{1}{|c|}{ Actions performed as a part of the individual tasks } \\
\hline Financial & - Development of balance sheet policy and principles of accounting, \\
- Bookkeeping & - Keeping a registry of fixed assets, depreciation, and revaluations \\
pursuant to balance sheet and tax law, \\
- Managing settlement and keeping remuneration records as required \\
by balance sheet and tax law, \\
- Issuing invoices and other accounting documents in connection with \\
the operations of the contracting party, \\
- Drafting reports on entity activities, \\
- Drafting periodic financial reports in agreement with the Act on \\
Accountancy, and
\end{tabular}

Sourse: Nadolna (2007, p. 220-221).

\section{Entities Rendering Financial and Accounting Services in Poland}

Poland has a developed market of entities providing financial and accounting services. Outsourcing service suppliers can be subdivided in terms of their market position and scope of services. The largest entities providing financial and accounting services for external customers are business process outsourcing centers (BPOC) and shared service centers (SSC). A total of $46 \%$ of the processes performed by these entities involve finance and accounting (Ten Years of the BBS Sector in Poland Report). Accounting offices make up the next group. Data from the Starter Foundation for the year 2013 shows that there were 45,250 accounting offices in Poland, of which each served twenty-five companies, on average. The last group of entities is formed by independent accountants who manage accounting and tax records. Starter Foundation research indicates that in 2013 there was an increase in the number of entities declaring use of traditional accounting offices (by a total of $11 \%$ ) and using accounting programs (by $2 \%$ ). Simultaneously, this was accompanied by a decrease in entities keeping their books by hand or using spreadsheets (from $12 \%$ in 2011 to $5 \%$ in 2013) and a decrease in the number of entities employing 
accountants (from $12 \%$ in 2011 to $9.5 \%$ in 2013) (Starter Business Development Foundation). Among the reasons for these changes is the increase in the number of accounting offices and independent accountants providing accounting services as well as the ongoing reluctance to use online solutions.

The provisions of the Act on Accountancy indicate that the managing of accounting books can be contracted to external entities. It lists who may manage accounting books as a service activity. To date, such activities were exclusively reserved for persons holding certification as accountants, tax advisors, and expert auditors. Accountant certification was issued by the Ministry of Finance to confirm a person's qualifications on the basis of education and work experience or on the basis of a successfully passed examination. As of August of 2014, pursuant to Article 76a, Clause 3 of the Act on Accountancy, all businesses can provide service in the managing of accounting books assuming that the activities in this area are performed by persons with full legal capacity who have not been sentenced by an effective decision of the court for crimes against the credibility of documents, property, economic turnover, turnover in cash and securities, or for treasury offences. They do not have to hold any special certification or have any defined education or experience in accounting. There is no longer any requirement to hold accountant certification as issued by the Ministry of Finance for undertaking activities involving the managing of accounting books as a service. Nevertheless, anyone holding an accountant certificate or certification of qualification as issued on the basis of earlier regulations can continue to use them as proof of professional qualifications.

The primary task of accounting as an information-auditing system and as an economic measurement system is the creation by way of financial reporting of a credible picture of the potential and achievements of an economic entity. The effective attainment of this goal requires the professional accountant to not only maintain accounting books diligently and to properly present financial reports, but also monitor, investigate, and interpret such reports (Micherda and Swietla, 2014). Thus, what is necessary in order to reliably perform work related to the rendering of financial and accounting tasks and the process of properly documenting and settling taxes is professional knowledge and skills.

Among the benefits of the outsourcing of financial and accounting services are the lowering of operating costs as derived from specialization and the benefits of scale on the part of the external supplier, savings in time and resources, the attracting of external highly-qualified personnel and the ability to use expert knowledge, the experience of an external partner, and access to specialized technology.

Companies that decide to use outsourcing in their financial and accounting processes can also achieve additional targets such as attracting a competent partner representing the company before publiclegal bodies, the transfer of a part of the liability for incorrectly calculated tax liabilities onto the supplier of outsourced services, and release from the need to employ and train suitably qualified staff in the area of accounting and finance (Zieliński, 2008).

\section{Type, Scope, and Quality of Accounting Services as Provided by Accounting Offices in Poland}

The results of a study on a group of 600 respondents, representatives of the SME sector and accounting offices as found in the "One Year after Deregulation" Report, were presented at the Accountants of the Future Conference in June of 2015. The report shows that accounting services used by businesses involving the entrusting of company bookkeeping to external services encompass:

- Servicing settlement with the State Treasury $-89 \%$,

- Settlement with the Social Security Administration - 88\%,

- Formal and accounting monitoring of documents $-85 \%$,

- Maintaining records for the settlement of the tax on goods and services (VAT) $-88 \%$,

- Managing accounting books $-76 \%$,

- Representing the company before the Social Security Administration - 78\%,

- Drafting salary lists and managing employee files $-78 \%$,

- Representing the company before the Treasury Authorities - 78\%, and

- Managing tax expenditure and revenue ledgers $-58 \%$. 
The above information indicates that this is primarily a matter of basic operations tied to the proper settlement of accounts and taxes. Barely $3 \%$ of businesses named "other services." This raises a question: Is it a case of businesses not needing other services such as advisory, analytical, and company financial result analyses, or do accounting offices fail to offer such services?

Moreover, the above data show that in selecting an office it was price, range of services, and the opinions and recommendations of other companies that were important. However, the order of these three factors is different in the case of business and accounting office representatives. In the view of accountants, price is the most important factor. Businesses, for their part, looked to the scope of offered services. Figure 1 presents the share of respondents who replied to the question of how the range of offered services is seen as a criterion for choosing an accounting office.

A very important conclusion stemming from the results presented in Figure 1 is the fact that businesses consider the range of offered services to be decidedly relevant $(44.6 \%)$ and rather relevant $(38 \%)$ when selecting an accounting office. Accountants tend to indicate this criterion somewhat less $(33.7 \%$ decidedly relevant and $40.4 \%$ rather relevant). Cause for concern is the fact that almost $7 \%$ of accountants think the scope of services is rather irrelevant in selecting an accounting office as the supplier of outsourced services.

No questions regarding the quality of provided services made their appearance in the study. However, respondents were asked if they came across cases of incompetence and dishonesty on the accounting services market. A total of $34 \%$ met with glaring instances of incompetence. Businesses, for their part, almost do not see this problem (4\% of indications) ("One Year after Deregulation" Report). This might be a case of a lack of knowledge on the part of entrepreneurs regarding accounting office incompetent staff. In spite of the negative view of the deregulation of the profession and significant concerns regarding this phenomenon, relatively few accounting offices decided to introduce organizational changes, additional training for personnel (4\%), and expanding their range of offered services $(9 \%)$ that would aid them in finding a place on the more competitive market.

The most important criteria in the process of employment of new workers were professional experience and specialized education in the view of respondents from accounting offices. Familiarity with computer programs took a third position. Over one-half of respondents also appreciated seniority as well as training and courses. However, holding a certificate was important for less than $40 \%$ of those examined and more than $30 \%$ thought this factor to be completely irrelevant. Research has

Figure 1. To what extent does the range of offered services determine choice of accounting office (percentage of indications)?

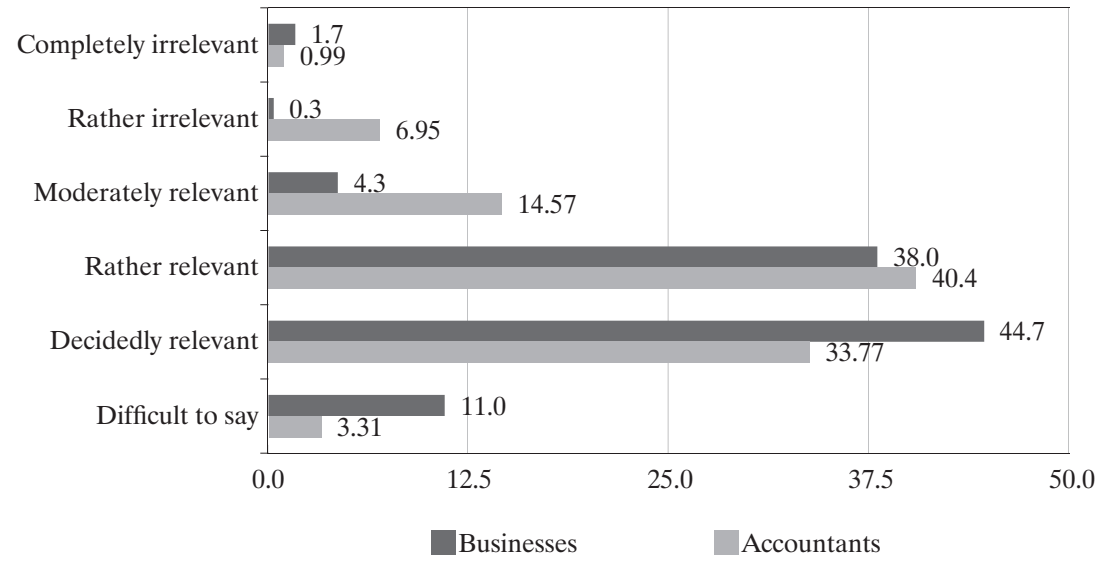

Source: developed on the basis of the "One Year after Deregulation: The Accounting Market after the Freeing of the Profession" Report [in Polish] Warsaw, June (2015). www.ksiegowiprzyszlosci.pl. 
shown that knowledge combined with practice are the main determinants in recruiting employees to accounting offices. Accounting office owners are fully aware of the fact that only human capital equipped in knowledge and skills can guarantee the proper functioning of the office and its development and so employ suchworkers.

\section{Determinants Shaping Demand for the Outsourcing of Accounting Services in Light of Research}

In this age of the extreme importance of knowledge, information, and technology, businesses should also seek suppliers of financial and accounting services who offer services of high quality and broad assortment. Demand for outsourced services should primarily stem from a demand for specialized knowledge and this factor should be of greatest importance in selecting a service provider.

A pilot study was conducted on a group of fifty-six entrepreneurs from the Podlaskie Voivodeship who used accounting office services in order to determine the deciding premise regarding the outsourcing of accounting services. The respondents were the customers of three randomly selected accounting offices located at three different locations - a major city, a mid-sized town, and a village. One hundred questionnaires were forwarded to these customers with the consent of the accounting office owners. The rate of return was $56 \%$.

The questionnaire was made up of thirty closed questions subdivided into four groups:

1) Identification of factors responsible for the decision to have an outside company manage accounting;

2) Determinants behind deciding to undertake collaboration with the current accounting office;

Figure 2. Characteristics of the Sample
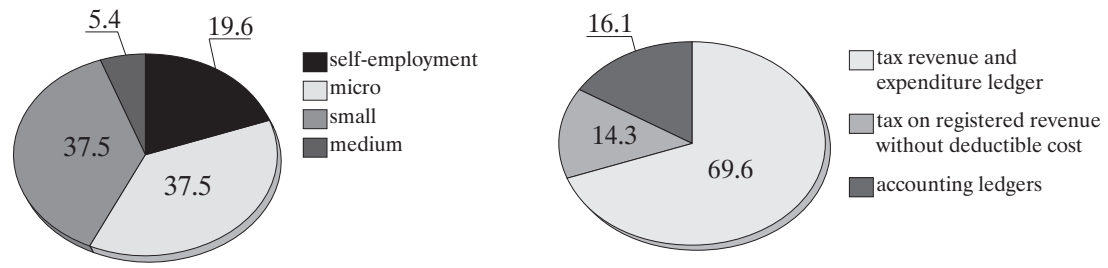

3) Factors determining the extension of collaboration for a successive year;

4) An assessment of collaboration with the accounting office.

Responses were presented as a set of affirmative sentences provided with a numerical Likert scale depicting the following intensities: 1 - Decidedly not, 2 - Rather not, 3 - Rather yes, and 4 Decidedly yes. No "I don't know" answer was provided in order to mobilize the respondent to define their answer. An open question was proposed following each set of answers in order to define other factors. However, no such factors were indicated, which may mean that the businessmen identify similar determinants to those proposed in the statements.

Thirty-five men and twenty-five women took part in the study. A total of $64.3 \%$ of those examined hold a master's degree, while $21.4 \%$ only have a first level college degree. A total of $50 \%$ have been managing their company for four to five years, while $28 \%$ have been doing so for two to three years. New companies of up to one year account for $7 \%$, while only $5 \%$ have been in operation for more than five years. Micro companies employing up to nine workers were dominant in the group $(37.5 \%)$, together with small companies employing from ten to forty-nine workers (also 37.5\% of those studied). Self-employment was the case for $19.6 \%$ of the respondents, while $5.4 \%$ of the serviced companies were ranked in the group of medium-sized companies fifty to 250 employees. The largest share of the businesses make settlements using a tax revenue and expenditure ledger $-69.6 \%$. A total of $16.1 \%$ have accounting books, while $14.3 \%$ are taxed on registered revenue without deductible costs (Figure 2).

The first part of the study pertained to the identification of factors responsible for deciding to have an external company manage

Source: Results from questionnaires.

Wydział Zarządzania UW ～DOI 10.7172/1733-9758.2016.20.4 
Figure 3. Which of the listed factors are behind the decision to have an external company manage accounting?

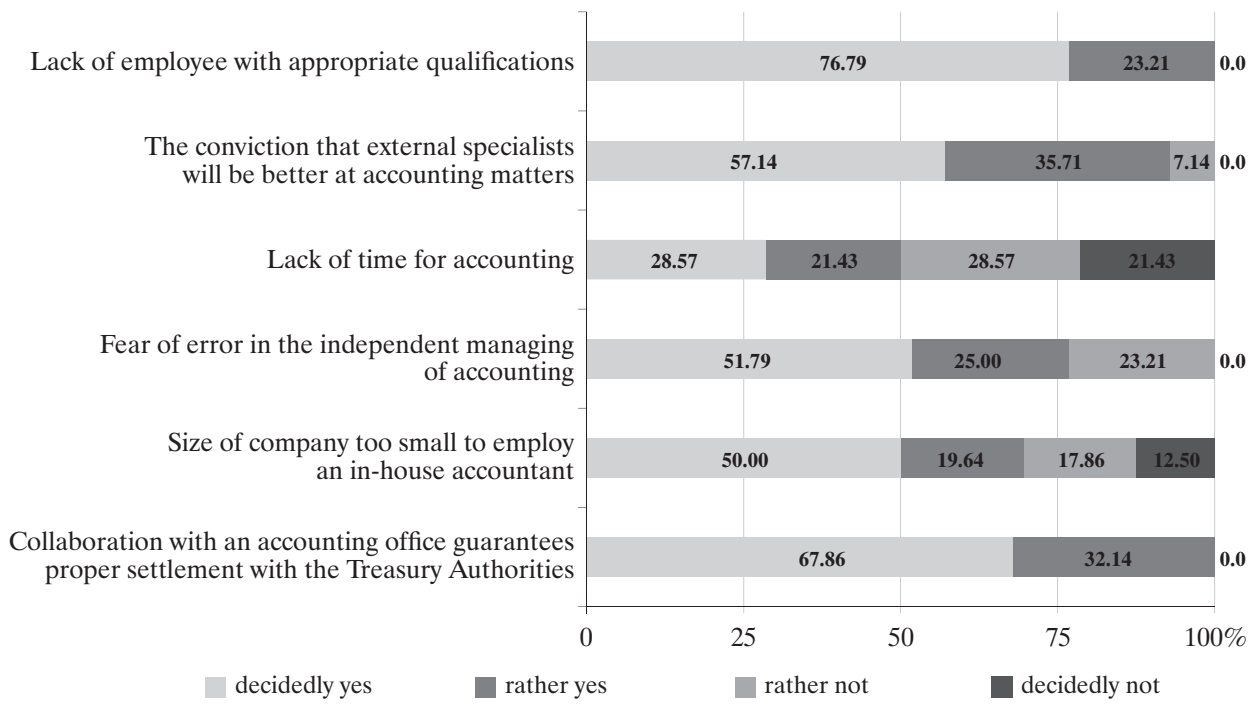

Source: Results from questionnaires.

accounting. In this group, the most important statements that determined use of outsourcing for accounting services were (Figure 3 ):

- Lack of an employee holding the appropriate qualifications $(77 \%$ decidedly yes and $23 \%$ rather yes),

- Confidence and trust as to the knowledge and competency of the staff of the accounting office defined by the statement that collaboration with the accounting office guarantees proper settlement with the Treasury Authority (68\% decidedly yes and $32 \%$ rather yes),

- The conviction that external specialists are better at accounting matters $(57 \%$ decidedly yes and $36 \%$ rather yes), which also stresses the major role of the knowledge and skill of accounting office staff, and

- The fear of errors emerging in the case of independent management of accounting $(52 \%$ decidedly yes and $25 \%$ rather yes), where this statement also indicates a lack of relevant knowledge on the part of the owner that would make possible the proper managing of revenue and expenditure ledgers and this is in spite of the fact that most respondents are college graduates - they fear independent settlement and prefer these operations to be performed by an external company.

In the second part, respondents were asked what factors were responsible for their choice of office presently providing them with accounting services. The most important factors were:

- Offered scope of services $(66 \%$ decidedly yes and $34 \%$ rather yes),

- The opinions and recommendations of other companies $(54 \%$ decidedly yes and $30 \%$ rather yes), and

- Offered assistance in selecting an optimum form of taxation of economic activity (43\% decidedly yes and $47 \%$ rather yes). The above-listed determinants confirm that the range of services, their quality, advisory services offered, assistance in decision-making, and recommendations from other office customers are more important than other factors in the decision. The price of accounting services, in first place in the "One Year after Deregulation" Report, was very important for only $10 \%$ of respondents in this study and rather yes for $19 \%$. A total of $30 \%$ of those examined state that price, accounting office size, and certificates held rather do not influence selection of service provider. A total of $40 \%$ completely reject them as factors determining choice of the present office. What is interesting it that for $68 \%$ of those studied, the accounting office's insurance coverage is also unimportant. Trust in the knowledge and competencies of office staff are behind the decision of businessmen to start collaboration (Figure 4). 
Figure 4. Which of the listed factors were behind selection of the accounting office currently managing company accounting?

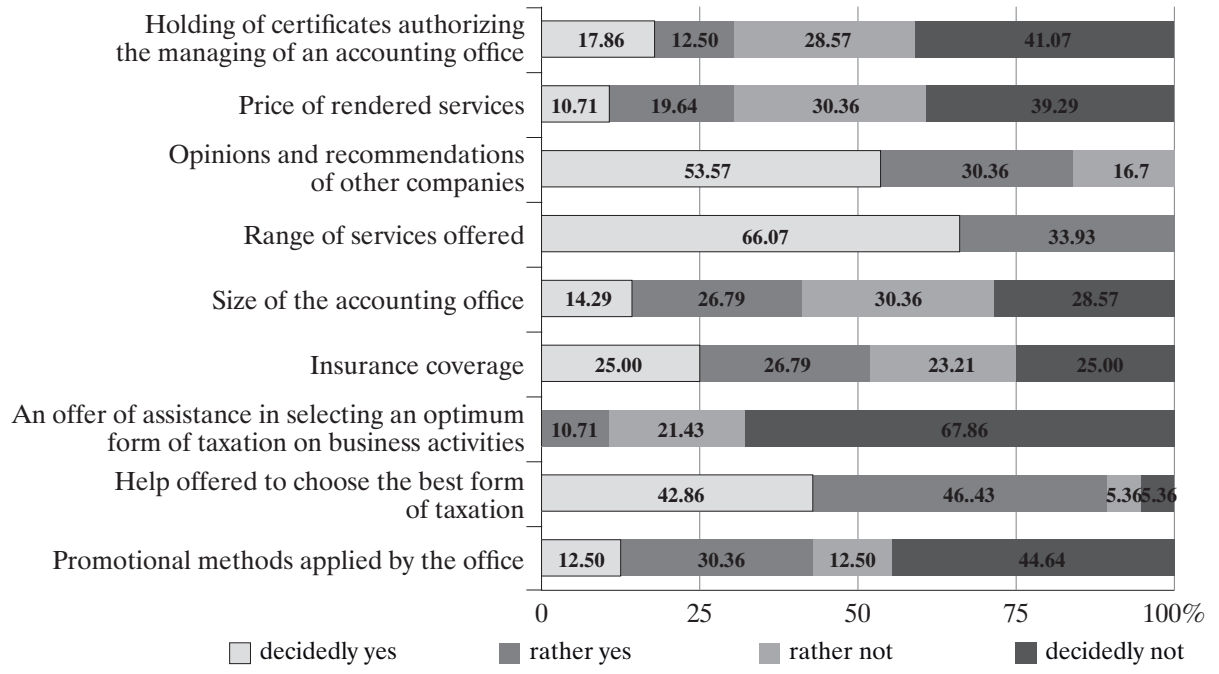

Source: Results from questionnaires.

The next part of the study acquired information on factors responsible for extending collaboration for a successive year. The largest number of respondents stressed the proper managing of accounting, the possibility of receiving information regarding running financial matters, appropriate collaboration, assistance in receiving credit an EU funding, and timely performance of tasks. Somewhat fewer indications related to selection of an accounting office as a result of competent employees providing assistance in choice of optimum solutions. Perhaps this was the result of the lack of advisory services being provided (Figure 5).

Figure 5. What factors were responsible for a decision to extend collaboration for a successive year?

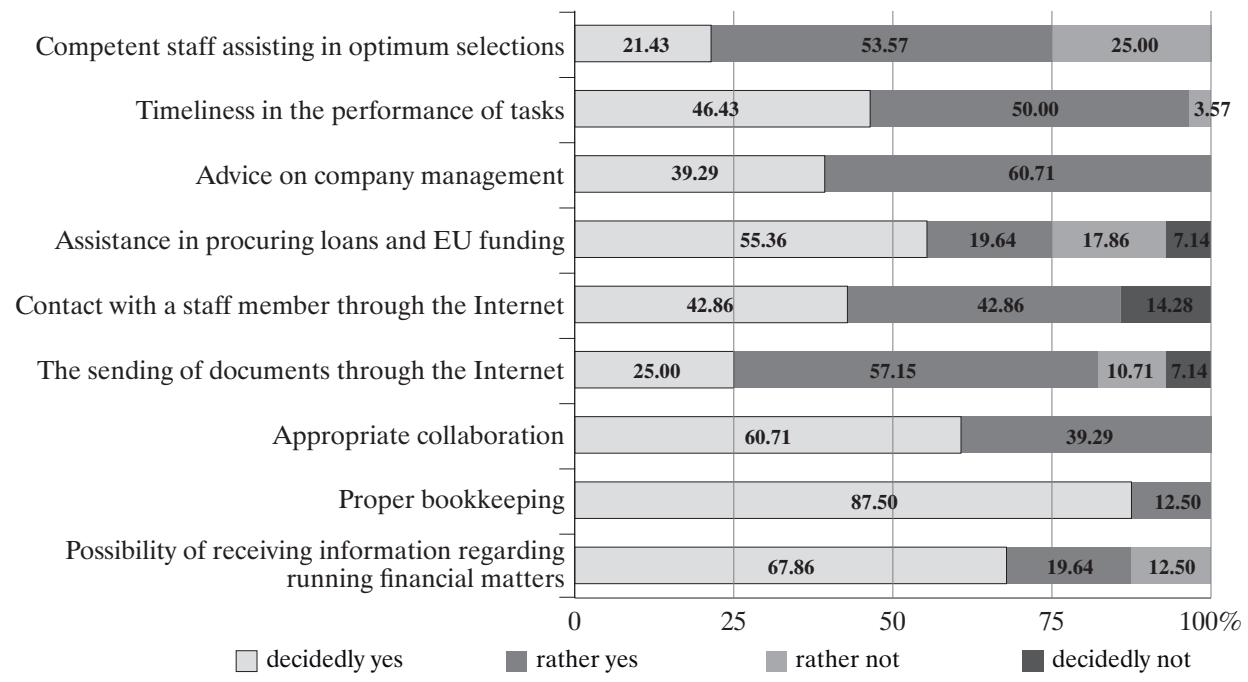

Source: Results from questionnaires. 
Figure 6. How would you rate collaboration with the accounting office?

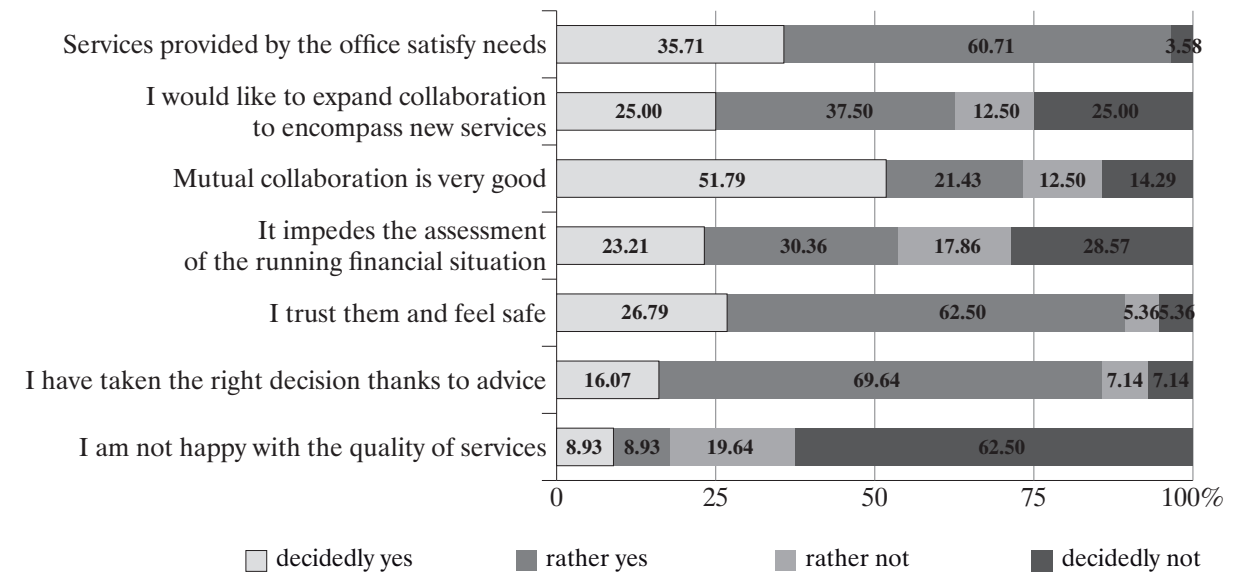

Source: Results from questionnaires.

The last area of analysis was the assessment of collaboration with the accounting office. A total of $52 \%$ of those examined rated collaboration very highly. As to services as rendered by the office satisfying company needs, $36 \%$ chose decidedly yes, while $61 \%$ rather yes. Moreover, businessmen trust office staff and collaboration provides them with a sense of safety. However, a certain share of respondents agree with the statement that accounting managed by an external office impedes the running assessment of the company and are considering the employment of an in-house accountant (23\% decidedly yes and 30\% rather yes) (Figure 6).

\section{Summary}

The accounting services market has noted its most dynamic development over the past few years. Newly emerging offices are offering an ever-increasing gamut of services. The outsourcing of financial and accounting services is increasingly often treated as a part of a comprehensive process aimed at raising the dynamics and efficiency of company operations. Access to the knowledge and tools provided by the service supplier makes possible the acquisition of information thanks to which it becomes possible to make the right decisions and achieve better operating results. Fragmentation, the result of which is the outsourcing of accounting, took place as a result of a decision to concentrate on costs. In its current phase, it is evolving towards a seeking of additional benefits from outsourcing agreements. Such benefits include the utilization of the knowledge and skills of specialists not only for basic financial and accounting services, but also for additional analyses, assessment of the financial situation, help in procuring financial resource from outside sources, etc.

Misgivings on the part of accountants fearing that price will become the main determinant in selecting a service provider have proved baseless. Price is important, but it is not the main factor driving choice. The studies contained in the "One Year after Deregulation" Report have pointed to a somewhat different perception of price and scope of services as factors determining selection of the office providing services. Questionnaire-based studies have also indicated that this is a less important factor.

Thus, if price is not the factor that causes the selection to be economically effective then this means that other non-cost determinants make the choice beneficial from the point of view of the entity. Studies by these authors and those in the ksiegowiprzyszlosci.pl portal allow the formulation of the hypothesis that other factors, to a greater extent than price of services, are behind the development of the outsourcing of financial and accounting services as provided by accounting offices in Poland.

However, it was not possible to unequivocally verify the statement that the grow- 
ing demand for specialized knowledge is a very important factor in the development of the outsourcing of services rendered by accounting offices due to the fact that the sample was too small. However, it can be decidedly stated that this pilot study has shown that entrepreneurs stress the importance of workers with appropriate qualifications, they are assured by and trust in the knowledge and competencies of office staff, and undertake collaboration with an accounting office because this guarantees proper settlement with the Treasury. They are convinced that external specialists will take care of accounting matters better than they could themselves. Approximately $84 \%$ of respondents make their tax settlements using simplified forms, e.g., revenue and expenditure ledgers. Contracting out bookkeeping to an accounting office is not the result of a lack of time on the part of the owner to take care of accounting matters. The primary reason is fear that errors might find their way into the records. This indicates a lack of the relevant knowledge on the part of owners regarding proper settlement. Moreover, the scope of offered services, their quality, and proposed advisory services and assistance in decision-making certified by the opinions of other office customers are a more important determinant that other factors.

On the basis of the conducted research it is possible to state that the outsourcing of financial land accounting services as offered by accounting offices catering to small and medium companies will develop when:

- The proposed scope of services will encompass not only basic services in the area of financial and tax accounting, but also management accounting,

- The quality of provided services will be on a high level and collaboration with the customer, Treasury Authorities, Social Security Administration (ZUS), and the accounting office will be proper,

- Staff will have relevant knowledge, skills, competencies, and experience,

- Greater attention shall be paid to the development and training of office personnel - raising their abilities - than on price competition,

- Promotion of the accounting office shall simultaneously be an information campaign regarding the possibility of additional specialized services meeting the needs of entrepreneurs,
- Information regarding the financial situation of the company as stemming from bookkeeping entries and financial reporting shall be provided to the customer on a running basis, and

- Employees shall provide advice in making financial decisions.

In deciding to launch collaboration with an accounting office, the company expects not only lower costs (as compared with the employment of a worker), but primarily higher quality of services. These are benefits that can be achieved when using the services of an outsourced company with high-quality specialists, access to knowledge, software, and modern technologies, as compared to the execution of the accounting function within company structures.

In connection with the continuously growing level of complexity of financial and accounting problems touching the entrepreneur, the service market in this area must develop continuously - the training of new workers and the employment of new specialists. More and more entities offer comprehensive services in the area of both accounting and financial and tax advisory services. This is a successive step in the advance of outsourced services providing the customer with greater benefits as stemming from collaboration with an entity that has at its disposal comprehensive knowledge regarding the problems of the company and that can propose appropriate solutions encompassing questions of functioning in whole.

\section{Footnote}

1 The research have been carried out the framework of work S/WZ/02/15 and funded by the Ministry of Science and Higher Education.

2 Opinions expressed during the Accountants of the Future Conference, organized by the Association of Accountants in Poland on June 10, 2015 in Warsaw.

\section{References}

10 lat sektora nowoczesnych ustug biznesowych $w$ Polsce [Ten years of the modern business service sector in Poland]. Retrieved from: http:/www. mg.gov.pl/node/23452.

Ciesielska, D. and Radło, M.J. (2014). Outsourcing $w$ praktyce [Outsourcing in practice]. Warsaw: Poltext. 
Cyrek, M. (2012). Rozwój sektora ustug a gospodarka oparta na wiedzy [The development of the service sector and the knowledge-based economy]. Rzeszów: Wydawnictwo Uniwersytetu Rzeszowskiego.

De Vita, G. and Wang, C.L. (2006). Development of Outsourcing Theory and Practice: A Taxonomy of Outsourcing Generations. In: K.W. and V.P. Singh, Outsourcing and Offsourcing in the XXI Century: A Socio-Economic Perspective. London: Idea Group Publishing, http://dx.doi.org/10.4018/978-1-59140875-8.ch001.

Jarka, S. (2011). Stan i perspektywy rozwoju outsourcingu w Polsce [The state of outsourcing in Poland and perspectives for its development] Scientific Papers of the Warsaw University of Life Sciences. Ekonomika i Organizacja Gospodarki Żywnościowej [The economics and organization of the food economy], 93.

Jones, R.W. and Kierzkowski, H. (1988). The Role of Services in Production. Retrieved from: http:// www.econ.rochester.edu/people/jones/Role_of Services.pdf.

Jones, R.W. and Kierzkowski, H. (2003). International Fragmentation and the New Economic Geography. Retrieved from: http://www.econ.rochester.edu/people/jones/International\%20Fragmentation $\% 20$ and $\% 20$ the $\% 20$ New $\% 20$ Economic $\% 20$ Geography\%5B2\%5D.pdf.

Kuczewska, L. (2009). Stan i perspektywy rozwoju usług biznesowych w Polsce [The state of business services in Poland and perspectives for their development]. Handel Wewnętrzny [Domestic trade], 1.

Matejun, M., (2011). Proces outsourcingu w praktyce gospodarczej małych i średnich przedsiębiorstw [The process of outsourcing in the economic practice of small and medium companies]. In: W. Matwiejczuk (ed.), Dylematy organizacji gospodarczych. Teoria i praktyka poczatku XXI wieku [The dilemmas of economic organizations: Theory and practice at the beginning of the 21st century]. Warsaw: Difin.
Micherda, B. and Świetla, K. (2014). Wspótczesna rachunkowość $w$ świetle badań empirycznych [Contemporary accounting in light of empirical research]. Warsaw: Difin.

Nadolna, B. (2007). Outsourcing. In: K. Czubakowska (ed.), Od auditingu do sponsoringu w rachunkowości [From auditing to sponsoring in accounting]. Warsaw: PWE.

Pocztowski, A. (2003). Zarzadzanie zasobami ludzkimi: strategie, procesy, metody [Human resource management: Strategies, processes, methods]. Warsaw: PWE.

Radło, M.J. (2013). Offsourcing i outsourcing. Implikacje dla gospodarki i przedsiębiorstw [Offsourcing and outsourcing: Implications for the economy and companies]. Warsaw: SGH Publishers.

Rok po deregulacji. Rynek ustug ksiegowych po uwolnieniu zawodu [One year after deregulation: The accounting market after the freeing of the profession]. Warsaw, June, 2015. Retrieved from: www. księgowiprzyszlosci.pl.

Sajkiewicz, A. (2002). Jakość zasobów pracy: kultura, kompetencje, konkurencyjność [The quality of labor resources: Culture, competencies, competitiveness]. Warsaw: Poltext.

Tate, W.L., Ellram, L.M., Bals, L. and Hartman, E. (2009). Offshore Outsourcing of Services: An Evolutionary Perspective. International Journal of Production Economics, 120(2), http://dx.doi. org/10.1016/j.ijpe.2009.04.005.

Trocki, M. (2001). Outsourcing. Metoda restrukturyzacji działalności gospodarczej [Outsourcing. A method for restructuring economic activity]. Warsaw: PWE.

Zieliński, J. (2008). Outsourcing doradztwa podatkowego i rachunkowości $w$ matej firmie [The outsourcing of tax and accounting advisory services in a small company]. Cracow: Wolters Kluwer Polska. Act of September 29, 1994 on Accountancy (Journal of Laws of 1994, No. 121, item 591, with subsequent amendments). 